\title{
Playing Twenty-One with Mark Strand
}

You were reading us a poem...was it a William Meredith one, or a James Merrill Poem.... anyway, you read us the poem About a guy in his 30 s playing a pick-up Basketball game with teenagers in the Twilight, tired of his marriage, or inadequate In it, or his wife.... I don't remember.

You were a rising, young poet, who competed Again and again in lectures and Workshops With other 6os poets. Peg Carlson, was she The best, female poet in the Workshop and Not Catherine Davis, challenged you to a Pick-up game of 21, that ageless basketball Game. I thought of you telling us just before Christmas break, how you came into that Cellar hotel bar where we met for your class, You told us you had taken your '56 Green and white Ford to a gas station.... How the gas station attendant guessing you Were from the University asked what You did. You replied you were a poet And taught poetry and writing and he 
Ruffled your mind with a parting shot. "Oh, one of those.... seeing how big you are, I thought you were a football player."

Anyway, I got in on the pick-up game. We played next to Peg's apartment on A court of cement foul lines and correct Boundaries. While you measured shot After shot, lay-ups, jump shots, easing Them through the hoop like Bob Cousy, Or Chet Walker, I stayed the closest With you, and Peg was last. Did we play One game or two? Yes, a couple on a Sun washed court. Then we played a Scratch basketball game after 21 and You got all the rebounds, and neither Peg nor I were in your league.

Were the clouds milk white? Did our Breaths remain over that court? Did our Names empty our lives out leaving Our lives?

Where's Peg now, who cracked Up second semester? Where are you, Who no longer teach at Iowa? Did The Workshop go down the drain When we left? Yes, we're poets But other poets are there now in Workshops. 
We're soft muscles playing poet, and we're muscling Our poetry through America. $\mathrm{OH}$, Christ! We are Aging and playing 21 to us now is as green as the Current poets in the Workshops now.

What I remember is this.... we were on a bright Yellow court and the sun was blinding.... You missed a shot, Peg missed a shot, I missed a Shot.... Gimme the ball could be heard everywhere. The sun streaking through my name.... yellow, it Striped the court, and the stripes hit my back Now and then, and now and then. 